\title{
Temporal bone fractures: evaluation of 77 patients and a management algorithm
}

\author{
Temporal kemik kırıkları: 77 hastanın değerlendirilmesi ve bir yaklaşım algoritması
}

\author{
Gökhan YALÇINER, ${ }^{1}$ Ahmet KUTLUHAN, ${ }^{1}$ Kazım BOZDEMİR, ${ }^{1}$ \\ Hüseyin ÇETİN, ${ }^{2}$ Behçet TARLAK, ${ }^{1}$ Akif Sinan BİLGEN ${ }^{1}$
}

\section{BACKGROUND}

We aimed to evaluate the etiologies, otolaryngological features, radiological findings, management strategies, and outcomes of temporal bone fractures.

\section{METHODS}

Seventy-seven temporal bone fracture cases were retrospectively evaluated for age and gender distribution, side of the fracture, etiology of injuries, the presence of blood otorrhea, tympanic membrane perforation, cerebrospinal fluid otorrhea, hearing loss, hemotympanum, and facial or other cranial nerve palsies, and computerized tomography reports.

\section{RESULTS}

Nearly $55 \%$ of the cases were caused by traffic accidents and were predominantly male (76.6\%). Otolaryngological presentations in order to frequency were early conductive hearing loss $(65.8 \%)$, blood otorrhea $(61.2 \%)$, hemotympanum $(58.5 \%)$, tympanic membrane perforation $(25.6 \%)$, facial nerve paralysis $(12.3 \%)$, cerebrospinal fluid otorrhea $(8.5 \%)$, and sensorineural hearing loss (5.4\%). Most of the fractures were petrous (65.8\%) and longitudinal type (51.2\%).

\section{CONCLUSION}

In this research, otolaryngological findings in order of frequency and treatment approaches were compared with literature findings and discussed in 77 temporal bone fracture cases. We formed a management algorithm for the systematic evaluation and treatment of temporal fractures.

Key Words: Head trauma; maxillofacial injuries; temporal bone.

\section{$A M A C ̧$}

Temporal kemik kırığı olan hastalarda etyoloji, otolaringolojik semptom ve bulguların radyolojik değerlendirmeleri, tedavi yaklaşımları ve sonuçlar değerlendirildi.

\section{GEREÇ VE YÖNTEM}

Yetmiş yedi temporal kemik kırığı olgusu, yaş, cinsiyet, k1rığın yeri, kırığın etyolojisi ve kanlı otore, timpanik membran perforasyonu, serebrospinal otore, işitme kaybı, hemotimpanum, fasiyal ve diğer kraniyal sinir paralizilerinin varlı̆̆ı ve bilgisayarlı tomografi sonuçları yönünden geriye dönük olarak değerlendirildi.

\section{BULGULAR}

Olgularda kırıkların \%55'i trafik kazası sonucu meydana gelmişti ve çoğunluğu erkekti $(\% 76,6)$. Otolaringolojik bulgular sıklık sırası ile erken dönem iletim tipi işitme kayb1 $(\% 65,8)$, kanlı otore $(\% 61,2)$, hemotimpanum $(\% 58,5)$, timpanik membran perforasyonu $(\% 25,6)$, fasiyal sinir paralizisi $(\% 12,3)$, serebrospinal otore $(\% 8,5)$ ve sensörinöral işitme kaybı $(\% 5,4)$ idi. Kırıkların çoğu petroz $(\% 65,8)$ ve uzunlamasina tip $(\% 51,2)$ idi.

\section{SONUÇ}

$\mathrm{Bu}$ araştırmada 77 temporal kemik kırığı hastasında sıklık sırası ile otolaringolojik bulguları ve tedavi yaklaşımımızı literatür bulguları ile karşılaştırıp tartıştık. Temporal kırıklarda sistematik bir değerlendirme ve tedavi için bir algoritma oluşturduk.

Anahtar Sözcükler: Kafa travması; maksillofasiyal yaralanma; temporal kemik. 
Nowadays, head trauma is a common injury to which all of us are susceptible because of high speed travel. ${ }^{[1]}$ Skull fractures affect $23 \%-66 \%$ of patients with head trauma and approximately $4 \%-30 \%$ of head injuries involve a fracture of the cranial base, including $18 \%-75 \%$ of temporal bone involvement. ${ }^{[2,3]}$

After a severe head injury, the maintenance of life is the most important concern. After providing stable vital functions like breathing, circulation and neurosurgical evaluation and evaluation of the chest and abdomen, it is appropriate for an otolaryngologist to evaluate the patient. The importance of temporal bone fractures according to the otolaryngologist is the facial nerve and the structures related to hearing and balance located therein and prevention of functional losses. The most common physical examination findings of temporal bone fractures are blood otorrhea, tympanic membrane perforation, hearing loss, hemotympanum, cerebrospinal fluid (CSF) otorrhea, and facial and other cranial nerve palsies.

In this research, we retrospectively reviewed the causes, gender distribution, otolaryngological features, radiological findings, and outcomes of 77 temporal bone fracture cases between March 2007 and April 2011.

\section{MATERIALS AND METHODS}

Seventy-seven patients who were evaluated and treated for temporal bone fracture by our clinic between March 2007 and April 2011 and whose required data were obtained from their files were included in this retrospective research. Age, gender distribution, side of fracture (right, left, bilateral), etiology of injuries, presence of blood otorrhea, CSF otorrhea, tympanic membrane perforation, hearing loss (conductive, sensorineural or mixed), hemotympanum, and facial and other cranial nerve palsies, computerized tomography (CT) reports, and follow-up results were evaluated. The collected data were then analyzed and compared with the literature series.

\section{RESULTS}

Ages of the patients ranged from 8-76 years. Age, gender distribution, side of the fracture, and etiology of the injuries are seen in Table 1. In addition to the otolaryngologic examination, all patients were evaluated with axial and coronal $\mathrm{CT}$. In $\mathrm{CT}$, the fractures were evaluated according to two different classification systems as petrous-non-petrous and transverselongitudinal-oblique-mixed. The presence of blood otorrhea, tympanic membrane perforation, hearing loss (conductive-sensorineural-mixed), hemotympanum, CSF otorrhea, and facial and other cranial nerve palsies was noted according to the above classification systems.
Table 1. Distribution of cases according to age, gender, fracture side and mechanism of injury

\begin{tabular}{|c|c|c|c|}
\hline Total & & $\mathrm{n}$ & $\%$ \\
\hline \multirow[t]{8}{*}{ Age } & $8-10$ & 3 & 3.89 \\
\hline & $11-20$ & 10 & 12.98 \\
\hline & $21-30$ & 28 & 36.36 \\
\hline & $31-40$ & 12 & 15.58 \\
\hline & $41-50$ & 10 & 12.98 \\
\hline & $51-60$ & 8 & 10.38 \\
\hline & $61-70$ & 5 & 6.49 \\
\hline & $71+$ & 1 & 1.29 \\
\hline \multirow[t]{2}{*}{ Gender } & Male & 59 & 76.62 \\
\hline & Female & 18 & 23.37 \\
\hline \multirow[t]{3}{*}{ Side } & Right & 38 & 49.35 \\
\hline & Left & 34 & 44.15 \\
\hline & Bilateral & 5 & 6.49 \\
\hline & Traffic accidents & 42 & 54.54 \\
\hline \multirow{4}{*}{ of injury } & Falls & 19 & 24.67 \\
\hline & Industrial accidents & 12 & 15.58 \\
\hline & Assault & 3 & 3.89 \\
\hline & Gunshot wound & 1 & 1.29 \\
\hline
\end{tabular}

The facial and other cranial nerve palsies that were found in the first examination were counted as immediate and those found later (after the first few hours) were evaluated as late. The patients who were unconscious and were not appropriate for evaluation of hearing loss and facial function were ignored during the calculation of the percentages. Therefore, when calculating hearing loss and facial and other nerve functions, the total number of fractures was accepted as 73 , and the other ratios were calculated on the basis of 77 patients with 82 temporal fractures ( 5 patients had bilateral fractures). Results are seen in Table 2. Fourteen patients died of severe intracranial and other injuries.

\section{DISCUSSION}

Temporal bone fractures occur from high energy mechanisms, particularly as a result of side impacts, typically but not limited to motor vehicle accidents. ${ }^{[4]}$ In the literature, risk factors for and causes of temporal bone fractures are: younger age, male gender and motor vehicle accidents. ${ }^{[5-8]}$ Similarly, in our series, traffic accidents were the primary mechanism of the injury, with a $54.5 \%$ ratio; $76.6 \%$ of the cases were male and the mean age was 34.1 years. This result may be related to the fact that young males are greater participants in traffic and industrial business.

When otolaryngologists were consulted for the treatment of these patients, their primary concern was the evaluation of the external ear and tympanic membrane, the presence of blood otorrhea and CSF otorrhea, hearing status, facial nerve function, and the presence of hemotympanum. However, not infrequently, the severity of the injury, the patient's uncon- 
Table 2. Distribution of findings due to two different classification systems

\begin{tabular}{|c|c|c|c|c|c|c|c|c|}
\hline & Total & & $\begin{array}{c}\text { A } \\
(n, \%)\end{array}$ & $\begin{array}{c}\text { B } \\
(n, \%)\end{array}$ & $\begin{array}{c}C \\
(n, \%)\end{array}$ & $\begin{array}{c}D \\
(n, \%)\end{array}$ & $\begin{array}{c}E \\
(n, \%)\end{array}$ & $\begin{array}{c}\mathrm{F} \\
(\mathrm{n}, \%)\end{array}$ \\
\hline Total fracture & 82 & & $54,65.8$ & $28,34.2$ & $42,51.2$ & $21,25.6$ & $5,6.1$ & $14,17.1$ \\
\hline $\begin{array}{l}\text { Blood otorrhea } \\
\text { Tympanic } \\
\text { membrane }\end{array}$ & $51,62.1$ & & $43,52.4$ & $8,9.7$ & $33,40.2$ & $11,13.4$ & $3,3.6$ & $4,4.8$ \\
\hline perforation & $21,25.6$ & & $20,24.3$ & $1,1.2$ & $12,14.6$ & $6,7.3$ & $2,2.4$ & $1,1.2$ \\
\hline Hemotympanum & $48,58.5$ & & 41,50 & $7,8.5$ & $29,35.3$ & $12,14.6$ & $3,3.6$ & $4,4.8$ \\
\hline $\begin{array}{l}\text { Cerebrospinal } \\
\text { fluid otorrhea }\end{array}$ & $7,8.5$ & & $6,7.3$ & $1,1.2$ & $4,4.8$ & $1,1.2$ & - & $2,2.4$ \\
\hline Conductive hearing loss & $\begin{array}{c}50,64.9 \\
9,12.3\end{array}$ & $\begin{array}{l}\text { Immediate } \\
\text { Late }\end{array}$ & $\begin{array}{c}44,57.1 \\
7,9.5\end{array}$ & $\begin{array}{l}6,7.8 \\
2,2.7\end{array}$ & $\begin{array}{c}35,45.4 \\
4,5.4\end{array}$ & $\begin{array}{c}9,11.6 \\
3,4.1\end{array}$ & $\begin{array}{c}1,1.3 \\
-\end{array}$ & $\begin{array}{l}5,6.5 \\
2,2.7\end{array}$ \\
\hline $\begin{array}{l}\text { Sensorineural } \\
\text { hearing loss }\end{array}$ & $4,5.4$ & & $4,5.4$ & - & $3,4.1$ & $1,1.3$ & - & - \\
\hline Facial nerve palsy & $\begin{array}{l}3,4.1 \\
6,8.2\end{array}$ & $\begin{array}{l}\text { Immediate } \\
\text { Late }\end{array}$ & $\begin{array}{l}2,2.7 \\
6,8.2\end{array}$ & $\begin{array}{c}1,1.3 \\
-\end{array}$ & $\begin{array}{c}- \\
4,5.4\end{array}$ & $\begin{array}{l}2,2.7 \\
1,1.3\end{array}$ & $\begin{array}{c}- \\
1,1.3\end{array}$ & $\begin{array}{c}1,1.3 \\
-\end{array}$ \\
\hline $\begin{array}{l}\text { Other cranial nerve } \\
\text { (CN III, IV, VI) palsies } \\
\text { Meningitis }\end{array}$ & $\begin{array}{l}2,2.7 \\
1,1.3\end{array}$ & & $\begin{array}{l}2,2.7 \\
1,1.3\end{array}$ & $\begin{array}{l}- \\
-\end{array}$ & $\begin{array}{l}2,2.7 \\
1,1.3\end{array}$ & $\begin{array}{l}- \\
-\end{array}$ & - & $\begin{array}{l}- \\
-\end{array}$ \\
\hline
\end{tabular}

A: Petrous; B: Non-Petrous;C: Longitudinal; D: Transverse; E: Oblique; F: Mixed or comminuted.

scious status, and other severe injuries requiring urgent intervention lead to a delay in the otolaryngologic evaluation and management. After a physical examination for the establishment of an accurate fracture diagnosis, axial and coronal temporal CTs have a critical importance. ${ }^{[9,10]}$ We formed a management algorithm for the evaluation of temporal bone fractures. This algorithm format of temporal fracture management may offer a rapid experience opportunity for inexperienced practitioners (Fig. 1). To our best knowledge, no such algorithm has been reported to date.

There are several classification systems for the evaluation of temporal fractures with CT. Some of them are longitudinal-transverse-oblique or mixed, petrous-non-petrous, and otic capsule sparing-otic capsule violating. ${ }^{[2,3,6,7]}$ In the different series, statistical correlation between clinical findings and these classifications has been reported. ${ }^{[3,6]}$ In our series, we also evaluated the distribution of clinical findings according to petrous-non-petrous and transverse-longitudinal-oblique-mixed classifications. The distribution of fracture types and clinical findings due to these classifications are seen in Table 2. In our opinion, these classification systems may be important for statistical results, but are not clinically important, as we evaluate the patients according to the existence of the above-mentioned symptoms and findings and not the classification systems.

In our research, the most common otolaryngological findings were conductive hearing loss (CHL) in the early period $(64.9 \%)$, blood otorrhea $(62.1 \%)$, hemotympanum $(58.5 \%)$, and tympanic membrane perfora- tion $(25.6 \%)$. The hearing loss ratio in the early period is determined by the diapason test results of the first examination. This high ratio may be due to the high rate of hemotympanum and tympanic membrane perforations. After the average 4-6 week follow-up period, in patients with hearing loss, the CHL ratio was $12.3 \%$, which was determined by the audiologic examination. In the literature, the reported incidence rates for $\mathrm{CHL}$ were $10 \%-57 \%$. ${ }^{[3,7]} \mathrm{CHL}$ generally resolves over time (usually within 3-4 weeks). ${ }^{[2]}$ Pure hemotympanum generally resolves without sequelae within this time period as well. ${ }^{[2]}$ Small tympanic membrane perforation also heals within 4-6 weeks. If CHL and tympanic membrane perforations persist after 3 months, then tympanoplasty and, if necessary, ossicular chain reconstruction should be performed. ${ }^{[2]}$ The most common ossicular chain disruption is incudostapedial dislocation (11\%-14\%), followed by dislocation of the incudomallear joint. ${ }^{[3]}$ In our series, 5 patients underwent tympanoplasty, and 2 of them underwent incudostapedial joint repair with bone cement.

According to our research, the most common three symptoms (apart from early CHL), blood otorrhea, hemotympanum and tympanic membrane perforation, were seen above the rate of $90 \%$ with petrous fractures. Therefore, if a classification system has to be used, petrous-non-petrous classification seems more appropriate for otolaryngological purposes.

The sensorineural hearing loss (SNHL) rate was found as $5.4 \%$, and all of these cases were caused by petrous fracture. In the literature, SNHL rates were reported as $0 \%-14 \%{ }^{[2,7]}$ As is well known, there is no 


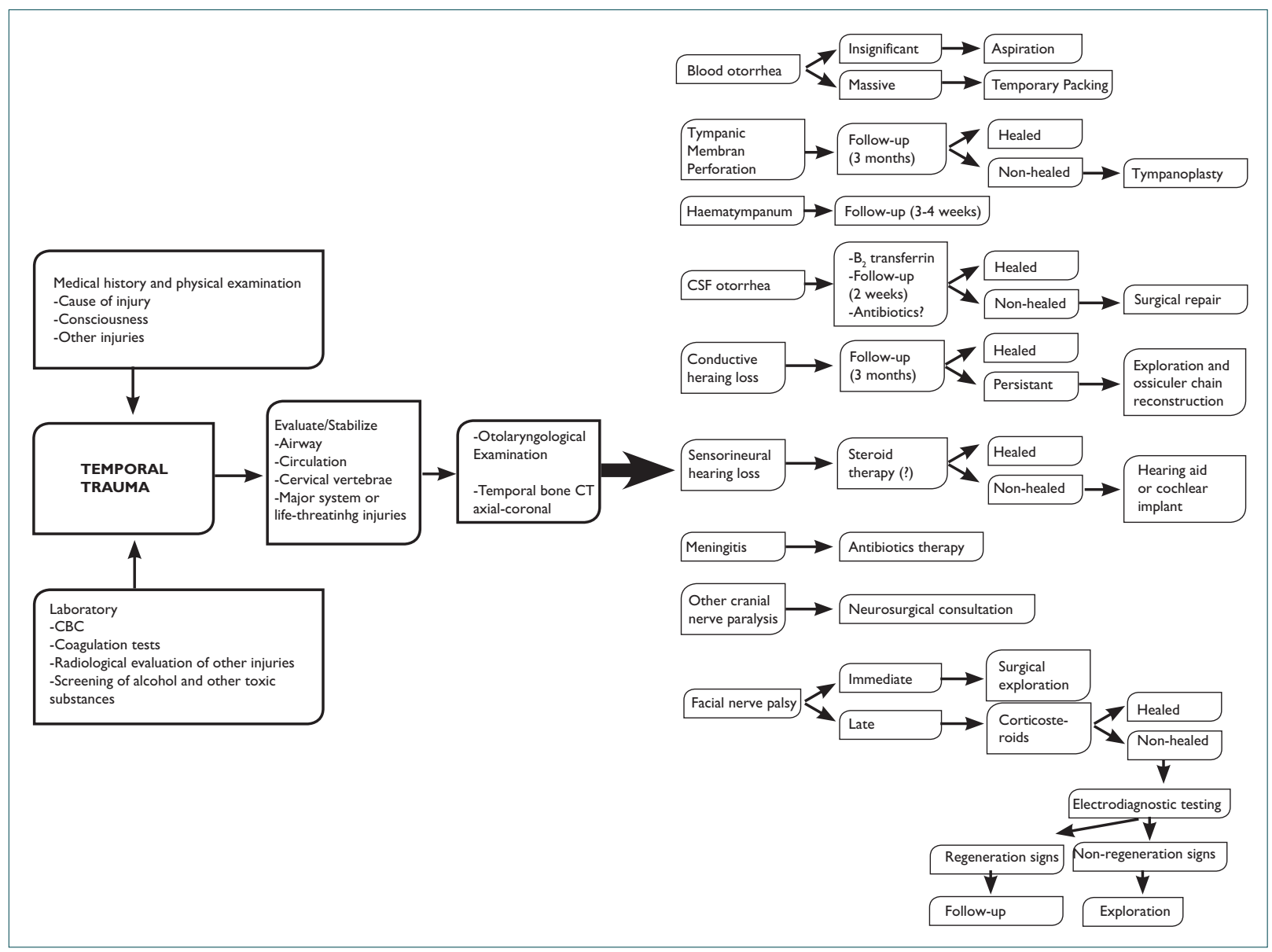

Fig. 1. The algorithm format of temporal bone fracture management.

effective treatment for SNHL, and rehabilitation with hearing aids, and if necessary cochlear implant, is recommended. Although there is not enough data in the literature about the usage of steroids for the treatment of SNHL due to temporal fracture, there is a possibility that they can be applied. We also do not have any experience about such treatment, but we intend to apply it in the future.

In our research, there were 9 facial nerve paralysis cases, with 3 of them having early or immediate and 6 having late onset (Fig. 2). All of the 6 paralysis cases with late onset were seen with petrous fractures and 2 of the 3 cases with early or immediate onset paralysis were seen with petrous fractures, while 1 had non-petrous, mixed type fracture. In the literature, facial nerve paralysis rates were reported as $10 \%-25 \%$ for longitudinal fractures and 38\%-50\% for transverse fractures. ${ }^{[3]}$ For transient and persistent facial paralysis, rates up to $65.5 \%$ were also reported. ${ }^{[11]}$ In our series, all of the late onset cases were given corticosteroid therapy and then followed up. All of them almost completely recovered. One of the early onset cases who also had 3rd, 4th and 6th cranial nerve paralysis died. One of them remained unconscious in the neurosurgical intensive care unit for 6 weeks and had septi- cemia. When his general condition improved, he had blindness due to optic atrophy and 3rd and 6th nerve paralysis on the facial paralysis side. His family did not accept surgery for facial nerve exploration.

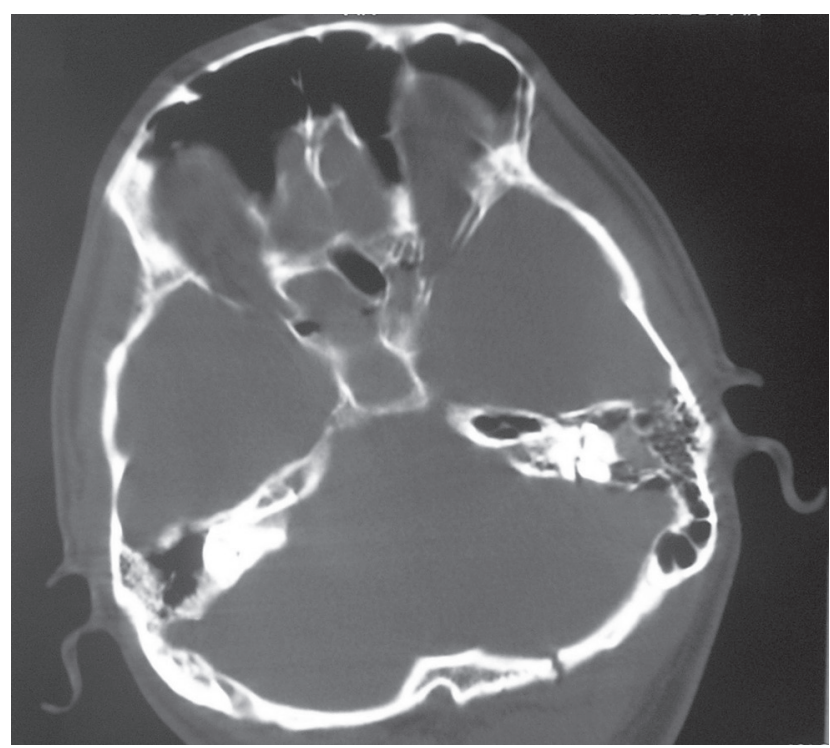

Fig. 2. CT of a patient with early facial paralysis showing transverse fracture. 
During the follow-up of the third patient in the intensive care unit for improvement in general status for the facial exploration operation, on the 20th day, signs of regeneration were detected in the electromyography and the operation decision was abandoned.

A generally accepted principle of the treatment of facial paralysis is that the management depends on the timing of paralysis related to the injury. ${ }^{[3]}$ Rapid loss of facial nerve function (immediate or within the first few hours) is likely due to transaction and is traditionally managed with surgical exploration after imaging and electrical studies indicate a need for nerve decompression or repair. On the other hand, a delayed loss is more likely due to edema and is typically treated with high-dose corticosteroids with further intervention based on results of the electrodiagnostic testing. ${ }^{[2,3]}$

Kim et al. ${ }^{[12]}$ reported that the patient with traumatic facial nerve paralysis who had nerve conduction studies consistent with a poor prognosis regained considerable facial function after early surgical intervention; however, late exploration did not result in a positive outcome.

Even though positive results have been reported in the literature with early surgery in selected cases, a recent systematic analysis revealed that the role of surgery versus nonsurgical interventions for this clinical entity remains inconclusive. ${ }^{[13]}$

There were 7 (8.5\%) CSF otorrhea cases in our research, 1 of which was seen with non-petrous fracture, and 6 of which were seen with petrous fractures. All of them were healed with conservative treatment (bed rest, head elevation, stool softeners, and prophylactic antibiotics). The reported incidence of CSF leak in temporal fractures ranges from $11 \%-45 \% \cdot{ }^{[3,7]}$ In the diagnosis of CSF, the presence of a halo around the blood on the sponge is often suggestive. In suspected cases, the $\beta 2$-transferrin test of the fluid is highly sensitive in identifying CSF leakage. ${ }^{[2]}$ With the above-mentioned conservative measures, CSF leaks will generally heal in two weeks. CSF leaks that persist longer than 10-14 days most likely require surgical repair. ${ }^{[2,3]}$ The use of prophylactic antibiotics remains controversial. However, in a meta-analysis, a significant increase in meningitis in patients who did not receive antibiotics was reported. Meningitis occurred in one of our patients who remained in the intensive care unit for a long time, but this patient did not have CSF leakage and healed with antibiotic treatment within three weeks.

One of the most common findings of temporal bone fractures is blood otorrhea. These bleedings usually stop spontaneously. In cases of massive bleeding, a temporary pack is placed into the external auditory canal. This pack should be removed in 24 hours and a prophylactic antibiotic should be given. In cases in which there is evidence of neurocranial injury on CT, angiography should be obtained in order to detect vascular injuries. ${ }^{[13]}$

In conclusion, temporal bone fractures generally occur as a component of a severe head trauma, and traffic accidents are the most common etiologic factor. An otolaryngologist is an important part of the team together with the neurosurgeon who cares for patients with temporal bone fracture. The event starts with the first evaluation of the patient in the emergency department and may continue with follow-up and treatment of otolaryngologically important features, such as CSF fistula or facial nerve paralysis, repair of tympanic membrane, and management of hearing loss. In some cases, a prolonged follow-up, up to a year, may be required for the treatment and rehabilitation of patients.

\section{REFERENCES}

1. Işık HS, Bostancı U, Yıldız O, Ozdemir C, Gökyar A. Retrospective analysis of 954 adult patients with head injury: an epidemiological study. Ulus Travma Acil Cerrahi Derg 2011; $17: 46-50$

2. Gladwell M, Viozzi C. Temporal bone fractures: a review for the oral and maxillofacial surgeon. J Oral Maxillofac Surg 2008;66:513-22.

3. Johnson F, Semaan MT, Megerian CA. Temporal bone fracture: evaluation and management in the modern era. Otolaryngol Clin North Am 2008;41:597-618.

4. Yoganandan N, Baisden JL, Maiman DJ, Gennarelli TA, Guan Y, Pintar FA, et al. Severe-to-fatal head injuries in motor vehicle impacts. Accid Anal Prev 2010;42:1370-8.

5. Ahmed KA, Alison D, Whatley WS, Chandra RK. The role of angiography in managing patients with temporal bone fractures: a retrospective study of 64 cases. Ear Nose Throat J 2009;88:922-5.

6. Ishman SL, Friedland DR. Temporal bone fractures: traditional classification and clinical relevance. Laryngoscope 2004;114:1734-41

7. Amin Z, Sayuti R, Kahairi A, Islah W, Ahmad R. Head injury with temporal bone fracture: one year review of case incidence, causes, clinical features and outcome. Med J Malaysia 2008;63:373-6.

8. Burgut HR, Bener A, Sidahmed H, Albuz R, Sanya R, Khan WA. Risk factors contributing to road traffic crashes in a fast-developing country: the neglected health problem. Ulus Travma Acil Cerrahi Derg 2010;16(6):497-502.

9. Hiroual M, Zougarhi A, El Ganouni NC, Essadki O, Ousehal A, Tijani Adil O, et al. High-resolution CT of temporal bone trauma: review of 38 cases. J Radiol 2010;91:53-8.

10. Saraiya PV, Aygun N. Temporal bone fractures. Emerg Radiol 2009; 16:255-65.

11. Yetiser S, Hidir Y, Gonul E. Facial nerve problems and hearing loss in patients with temporal bone fractures: demographic data. J Trauma 2008;65:1314-20.

12. Kim J, Moon IS, Shim DB, Lee WS. The effect of surgical timing on functional outcomes of traumatic facial nerve paralysis. J Trauma 2010;68:924-9.

13. Nash JJ, Friedland DR, Boorsma KJ, Rhee JS. Management and outcomes of facial paralysis from intratemporal blunt trauma: a systematic review. Laryngoscope 2010;120:1397404. 